\title{
First cases of Angiostrongylus cantonensis infection reported in Martinique, 2002-2017
}

\author{
Céline Dard ${ }^{1,2, a, *}$, Eve Tessier ${ }^{3, a}$, Duc Nguyen ${ }^{4}$, Loïc Epelboin ${ }^{5}$, Dorothée Harrois ${ }^{6}$, Christopher Swale ${ }^{2}$, André Cabié $^{4,7,8}$, \\ Katia de Meuron ${ }^{9}$, Charline Miossec ${ }^{3}$, and Nicole Desbois-Nogard ${ }^{3, *}$ \\ ${ }^{1}$ Laboratoire de Parasitologie-Mycologie, Centre Hospitalier Universitaire Grenoble Alpes, CS 10217, 38043 Grenoble Cedex 9, France \\ 2 Institute for Advanced Biosciences (IAB), INSERM U1209- CNRS UMR5309, Université Grenoble Alpes, 38700 La Tronche, France \\ ${ }^{3}$ Laboratoire de Parasitologie-Mycologie, Centre Hospitalier Universitaire de Martinique, Fort-de-France, 97200 Martinique, France \\ ${ }^{4}$ Service des Maladies Infectieuses et Tropicales, Centre Hospitalier Universitaire de Martinique, Fort-de-France, 97200 Martinique, \\ France \\ 5 Service des Maladies Infectieuses et Tropicales, Centre Hospitalier Andrée Rosemon, Cayenne, 97300 Guyane, France \\ ${ }^{6}$ Laboratoire de Biologie Médicale, Centre Hospitalier de Basse-Terre, Basse-Terre, 97100 Guadeloupe, France \\ 7 INSERM CIC 1424, Centre Hospitalier Universitaire de Martinique, Fort-de-France, 97200 Martinique, France \\ ${ }^{8}$ Université des Antilles, EA7524, 97200 Martinique, France \\ 9 Maison de la Femme, de la Mère et de l'Enfant, Centre Hospitalier Universitaire de Martinique, Fort-de-France, 97200 Martinique, \\ France
}

Received 5 January 2020, Accepted 28 April 2020, Published online 12 May 2020

\begin{abstract}
Neuroangiostrongyliasis is a parasitic disease caused by the accidental ingestion of the nematode Angiostrongylus cantonensis in its larval form. Human infection can lead to eosinophilic meningitis, sometimes complicated by life-threatening radiculomyelitis or encephalitis. Although some cases have been reported from otherCaribbean Islands, no cases have been diagnosed in Martinique so far. Here, we report the first eight laboratoryconfirmed cases of neuroangiostrongyliasis on the island of Martinique, French West Indies, between 1 January 2002 and 31 December 2017. One case was fatal and five resulted in neurological sequelae. The medical community should consider the risk of $A$. cantonensis infection in patients living in or returning from Martinique.
\end{abstract}

Key words: Angiostrongylus cantonensis, Angiostrongyliasis, Eosinophilia, Helminth, Meningitis, Encephalitis, Caribbean, Martinique.

Résumé - Premiers cas d'angiostrongylose à Angiostrongylus cantonensis à la Martinique, de 2002 à 2017. L'angiostrongylose neuroméningée est une maladie parasitaire causée par l'ingestion accidentelle du nématode Angiostrongylus cantonensis sous sa forme larvaire. L'infection humaine peut conduire à une méningite à éosinophiles, pouvant évoluer en radiculomyélite ou encéphalite menaçant le pronostic vital. Bien que des cas aient été rapportés dans d'autres îles des Caraïbes, aucun cas n'avait été diagnostiqué à la Martinique jusqu'à présent. Dans cet article, nous caractérisons les huit premiers cas d'angiostrongylose neuroméningée biologiquement diagnostiqués à la Martinique, Antilles françaises, entre le $1^{\text {er }}$ janvier 2002 et le 31 décembre 2017. Un cas s'est révélé mortel et cinq ont engendré des séquelles neurologiques. La communauté médicale doit désormais considérer le risque d'infection à $A$. cantonensis chez les patients vivant ou revenant d'un voyage à la Martinique.

\section{Introduction}

Angiostrongylus cantonensis is a nematode parasite that is the leading cause of infectious eosinophilic meningitis in humans in tropical and sub-tropical regions [6]. The life cycle involves rats as definitive hosts (mainly Rattus spp.) [49], various gastropods as intermediate hosts, and crustaceans [23], fishes and various other species as paratenic hosts [6].
Human infection is accidental, by ingestion of stage 3 larvae (L3) in gastropods or in paratenic hosts [11]. Neuroangiostrongyliasis is commonly a self-limited meningitis syndrome, but a large spectrum of clinical manifestations is possible [5]. Clinical manifestations range from asymptomatic disease and mild headaches to radiculomyelitis and encephalitis that can lead to permanent neurological injury or even death [29]. Most human cases of neuroangiostrongyliasis have been recorded

*Corresponding authors: dard. celine@gmail.com,nicole.desbois-nogard@chu-martinique.fr

${ }^{\mathrm{a}}$ These authors contributed equally to this work. 
in East and Southeast Asia, and the Pacific Basin, but the disease appears to be emerging in Australia [1], South America $[13,32,44]$, the United States [3, 21], and some islands of the Caribbean (Cuba, Haiti, Dominican Republic, Jamaica, and Guadeloupe) [12, 19, 42]. Several patients infected with A. cantonensis have been diagnosed with neuroangiostrongyliasis - but not reported in the scientific literature - during the last few years on the island of Martinique, a French overseas department in the Lesser Antilles with a population of 371,200 inhabitants as of 1 January 2018 (INSEE census, French National Institute of Statistics and Economic Studies, https:// www.insee.fr). The objectives of this study were to estimate the incidence and assess the clinical and biological features of neuroangiostrongyliasis in Martinique.

\section{Patients and methods} Study design

A retrospective single-centre observational study was undertaken at the University Hospital of Martinique - the main hospital on the island - spanning the period 1 January 2002 31 December 2017.

\section{Inclusion and exclusion criteria}

The following clinical and biological inclusion criteria were used: (i) neurological symptoms requiring lumbar puncture; (ii) eosinophilic meningitis defined as the presence of more than 10 eosinophils $/ \mathrm{mm}^{3}$ in the cerebrospinal fluid (CSF) or $\geq 10 \%$ of the total CSF leukocyte count [5]; and (iii) detection of antiA. cantonensis immunoglobulins in serum and/or CSF by indirect immunofluorescence assay (IIF) [22] or by western-blot (31-kDa antigen [34]). Patients with eosinophilia in the CSF due to a traumatic lumbar puncture or blood eosinophilia of another aetiology were excluded. Neuroangiostrongyliasis cases were defined as "confirmed" for patients who met the first two inclusion criteria, and with the detection of specific antiA. cantonensis immunoglobulins in serum and/or CSF by western-blot. When A. cantonensis serology was found to be positive by IIF only, cases were defined as "probable" because of the low/lack of specificity of this method for nematode infections, in which some cross-reactions can be observed $[47,48]$.

\section{Data collection}

Demographic data including exposure history, laboratory results (from blood and CSF), clinical presentation, imaging features (brain scan or MRI), and outcomes (recovery, sequelae, and death) were retrospectively collected from the medical charts, according to the legal and ethical guidelines of the French National Committee on Data Protection (CNIL).

\section{Angiostrongylus cantonensis serology by indirect immunofluorescence assays}

From 2002 to 2010, samples provided for A. cantonensis serological testing were sent to the only laboratory performing neuroangiostrongyliasis infection diagnosis in France, including its overseas regions (Laboratory of the Centre Hospitalier de Gonesse, Gonesse, France). An indirect immunofluorescence (IIF) assay was used for the detection of antibodies against A. cantonensis antigens, as described in [18]. Due to logistical constraints and availability of certain reagents, patient serodiagnosis in this laboratory ceased in 2010 and no other laboratory then performed the test in France. Subsequent serological analyses were therefore performed in Thailand or Switzerland by western-blot.

\section{Angiostrongylus cantonensis serology by western-blot}

Western blot assays using antigens derived from A. cantonensis adult worms were performed to detect IgG against A. cantonensis in either the Department of Parasitology, Faculty of Medicine Siriraj Hospital, Mahidol University, Bangkok, Thailand, or the Swiss Tropical and Public Health Institute, Basel, Switzerland. The detection of the 31-kDa band confirmed serum positivity as it shows high sensitivity and specificity ( $>99 \%$ for both) for the diagnosis of A. cantonensis infections [17].

\section{Results}

Descriptive results of the clinical presentations, including biological, imaging, and epidemiological features, are shown in Table 1 and statistically analyzed in Table 2. During the 16-year period of the study, four confirmed and four probable cases of neuroangiostrongyliasis were diagnosed in Martinique, among which three were children below 2 years of age, one was an 11-year-old boy, and four were adults aged from 37 to 64 years. The annual incidence rate was 0.14 cases $/ 100,000$ inhabitants/year (95\% CI [0.04-0.23]) with six of the cases occurring during the rainy season from June to November. All patients were born and lived in Martinique and none reported recent travel. Contact with molluscs was reported in two cases. All five patients older than 2 years of age (Table 1) presented with pre-existing mental disorders (pica syndrome, bipolar disorder, intellectual disability, or autism), which may have promoted the accidental or even deliberate consumption of snails. All cases presented with acute neurological signs and/or symptoms requiring a lumbar puncture: dysfunction of the cranial nerves (highlighted by clinical neurological examination of the 12 pairs of cranial nerves), headaches, axial hypotonia, seizures, radiculalgia, and neck stiffness. Clinical examination was difficult for one patient because of autism. During hospitalisation, five patients had fever and three had digestive symptoms (vomiting, abdominal pain, loss of appetite, and/or diarrhoea). Brain imaging was performed for all patients (CT scan or MRI): five presented abnormalities, with abnormal enlargement of the cerebral ventricles or cortical atrophy, and three were normal. Blood eosinophilia at admission was inconsistent, with a median of $1.72 \mathrm{G} / \mathrm{L}(13 \%$ of the WBC count in blood) and a range of 0.49-6.43 G/L (5-31\%). Median eosinophilia in the CSF at first lumbar puncture was 74.5 (25\% of the WBC count in CSF), with a range of $0-1550 / \mathrm{mm}^{3}(4-68 \%)$ 
Table 1. Description of the probable cases (numbers 1-4) and confirmed cases (numbers 5-8) of Angiostrongylus cantonensis infection in Martinique, including clinical, biological, imaging, and epidemiological features.

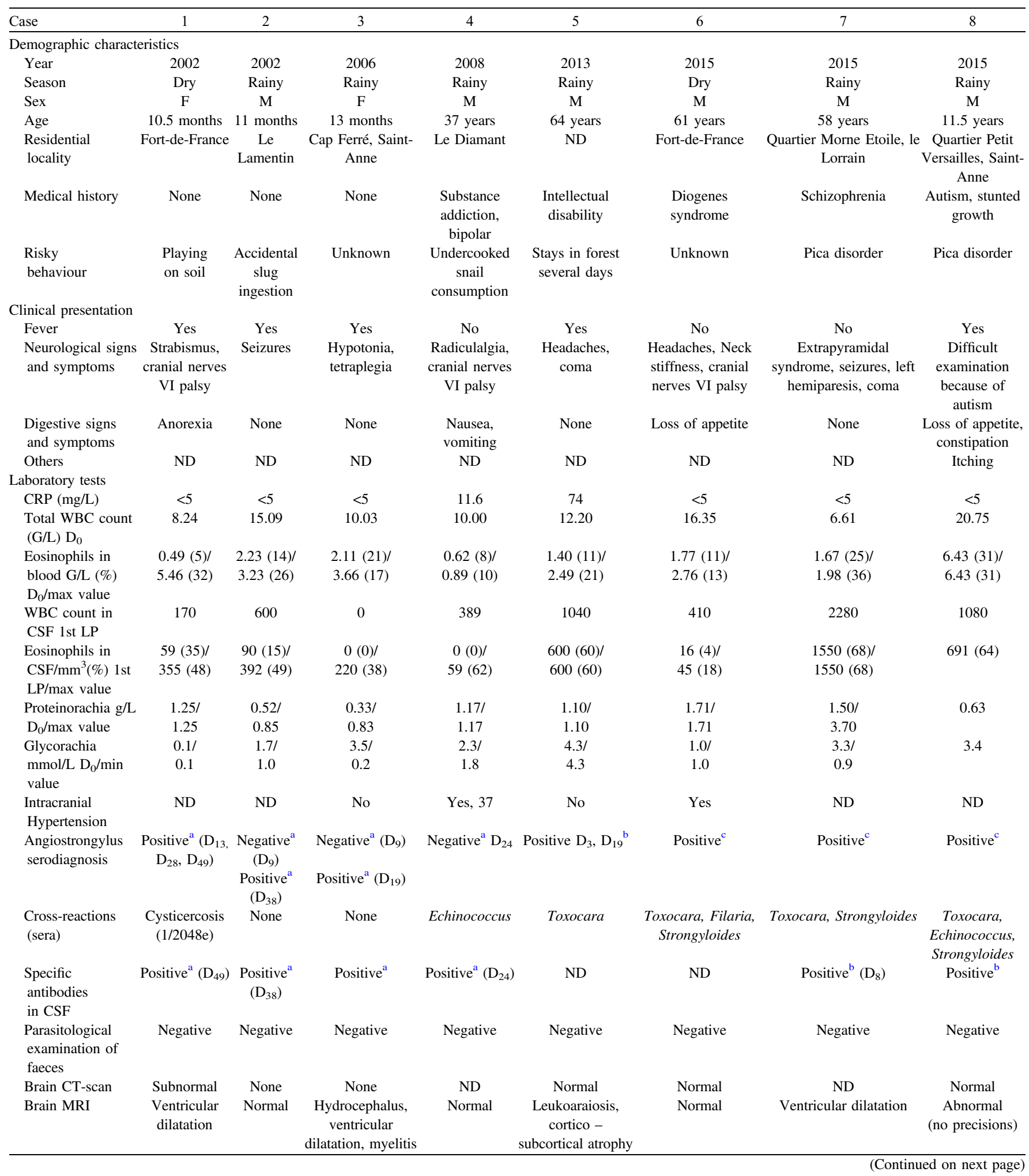


Table 1. (Continued)

\begin{tabular}{|c|c|c|c|c|c|c|c|c|}
\hline Case & 1 & 2 & 3 & 4 & 5 & 6 & 7 & 8 \\
\hline \multicolumn{9}{|l|}{$\begin{array}{l}\text { Management \& } \\
\text { outcome }\end{array}$} \\
\hline Treatment & $\begin{array}{l}\text { Thiabendazole, } \\
\text { albendazole } \\
\text { Subtractive LP }\end{array}$ & $\begin{array}{l}\text { Albendazole } \\
\text { Subtractive } \\
\text { LP }\end{array}$ & $\begin{array}{l}\text { Albendazole, } \\
\text { prednisone } \\
\text { Subtractive LP }\end{array}$ & $\begin{array}{l}\text { Subtractive } \\
\text { LP }\end{array}$ & $\begin{array}{l}\text { Albendazole, } \\
\text { prednisone } \\
\text { Subtractive LP }\end{array}$ & Albendazole + MPS & Albendazole +1 & Albendazole + MPS \\
\hline $\begin{array}{l}\text { Hospitalization } \\
\text { time (days) }\end{array}$ & 55 & 15 & 34 & 19 & 49 & $\begin{array}{c}66+90 \text { days of } \\
\text { physiotherapy }\end{array}$ & 20 & 16 \\
\hline $\begin{array}{l}\text { Clinical outcome, } \\
\text { sequelae }\end{array}$ & Strabismus & Recovery & $\begin{array}{l}\text { Psychomotor } \\
\text { retardation }\end{array}$ & Strabismus & Recovery & $\begin{array}{c}\text { Memory disorders, cranial } \\
\text { nerves VI palsy }\end{array}$ & $\mathrm{D}_{20}$ : death & Vision disorders \\
\hline
\end{tabular}

Abbreviations: CSF, cerebrospinal fluid; CT-scan, computerised tomography scan; CRP, C-reactive protein; Dx, day x after admission to hospital; LP, lumbar puncture; MPS, methylprednisolone; ND, not determined.

Normal values: CRP: $<5 \mathrm{mg} / \mathrm{L}$; protein level in CSF: $0.15-0.40 \mathrm{~g} / \mathrm{L}$; glucose level in CSF: $2.8-4.5 \mathrm{mmol} / \mathrm{L}$; intracranial tension: <20.

a Serology performed by indirect immunofluorescence in the Medical Center of Gonesse, France.

b Serology performed by western-blot analysis in the Department of Parasitology, Faculty of Medicine Siriraj Hospital, Mahidol University Bangkok, Thailand.

${ }^{c}$ Serology performed by western-blot analysis in the Swiss Tropical and Public Health Institute, Basel, Switzerland.

and the maximum values during hospitalisation were 373.5 $(54.5 \%)$, with a range of $45-1550 / \mathrm{mm}^{3}(18-68 \%)$. Most patients were treated with albendazole [35] and/or corticosteroids [18]. Clinical outcomes ranged from rapid recovery without sequelae for two patients to neurological sequelae manifested as strabismus and intellectual disability for five patients. One case was fatal for a 58-year-old man. Diagnosis was made by anti-A. cantonensis antibody detection in sera for seven patients and confirmed positive in CSF for five of them. One patient only showed detectable anti-A. cantonensis antibodies in the CSF. Serological analysis was negative for two patients nine days after admission, but positive 19-38 days after admission.

\section{Discussion}

This study reports the first eight laboratory-confirmed cases of neuroangiostrongyliasis in Martinique, which occurred between 2002 and 2017, thus extending the range of Caribbean islands with proven human cases of neuroangiostrongyliasis $[12,20,44]$. Given the potential lethality of neuroangiostrongyliasis, the medical community should therefore strongly consider the possibility of this infection in patients living in or returning from Martinique with eosinophilic meningitis.

In this study, neuroangiostrongyliasis cases occurred in two distinct epidemiological situations: three in infants less than 2 years old and five in patients over 11 years with mental diagnoses. The mode of transmission in infants was linked to poor living conditions with probable accidental consumption of contaminated snails or slugs when playing outside, as described on Mayotte, a French island in the Western Indian Ocean, in children under two years of age [18]. For adults, contamination was instead linked to intellectual disability associated with risky eating behaviour. In particular, pica syndrome may favour infection through the ingestion of gastropods usually not consumed as food in Martinique. No case was reported following consumption of raw paratenic hosts like shrimp, which is in contrast to the main source of infection in French Polynesia [35]. In our study, the diagnosis was initially unclear for all the patients and other kinds of helminthiases were initially suspected, as Martinique had never been reported as an endemic region for $A$. cantonensis. All but one of the patients were therefore treated with anti-helminthic drugs, although the efficacy and safety of albendazole or mebendazole for neuroangiostrongyliasis treatment remains controversial because of theoretical concerns that they may worsen the inflammatory response to dead and dying worms [5]. The four cases diagnosed after 2013 were also treated with corticosteroids, postulated to provide relief by reducing inflammation and thereby intracranial pressure and headache intensity $[9,43]$.

Comparison of the incidence of human neuroangiostrongyliasis in Martinique with neighbouring Caribbean Islands is straightforward. Indeed, cases were mainly reported in travellers returning from the Caribbean and it is likely that numerous autochthonous cases have not been reported in the scientific literature. Most Caribbean cases were reported in Cuba with several dozen cases since the 1980s [2, 36], mainly in the cities of Havana and Villa Clara [15, 16, 28, 37], and one case in a Swiss traveller returning from Cuba [7]. In Guadeloupe another French West Indies island - four autochthonous cases were diagnosed (to our knowledge) between 1999 and 2017 in young children who may have been in contact with infected molluscs ([12] and unpublished data), corresponding to an annual incidence rate of 0.053 cases per inhabitant per year (95\% CI [0.001-0.105]), close to that of Martinique. For the Dominican Republic, two suspected cases were reported in travellers returning to Europe [24, 41]. For Jamaica, twelve cases were diagnosed in adult travellers returning from Jamaica $[38,42]$, seven in autochthonous young children $[19,26]$ and one ocular case in a young woman [30]. No human cases have been reported in Grenada, the Bahamas, Haiti, and Puerto Rico, although $A$. cantonensis has been found in the environment on these islands [44]. It is noteworthy that the disease is also expanding in North and South America, in particular in the 
Table 2. Characteristics of the eight patients with eosinophilic meningitis caused by Angiostrongylus cantonensis.

\begin{tabular}{|c|c|}
\hline Characteristic & Result \\
\hline \multicolumn{2}{|l|}{ Demographic characteristics } \\
\hline Age (years) & $24.3[0.87-63.6]$ \\
\hline Sex (male) & $6(75 \%)$ \\
\hline Rainy season & $6(75 \%)$ \\
\hline \multicolumn{2}{|l|}{ Exposure risk } \\
\hline Reported contact with snails & $2(25 \%)$ \\
\hline Previous mental disorders & $5(63 \%)$ \\
\hline \multicolumn{2}{|l|}{ Clinical picture } \\
\hline Fever $\left(>38^{\circ} \mathrm{C}\right)$ & $5(63 \%)$ \\
\hline Digestive signs and symptoms & $3(38 \%)$ \\
\hline Neurological signs and symptoms & $8(100 \%)$ \\
\hline Headaches & $2(25 \%)$ \\
\hline Neck stiffness & $1(13 \%)$ \\
\hline Dysfunction of cranial nerves & $3(38 \%)$ \\
\hline Seizure & $2(25 \%)$ \\
\hline Axial hypotonia, hemiparesia & $2(25 \%)$ \\
\hline Radiculalgia & $1(13 \%)$ \\
\hline Coma & $2(25 \%)$ \\
\hline \multicolumn{2}{|l|}{ Brain imaging } \\
\hline Normal & $3(38 \%)$ \\
\hline Enlargement of cerebral ventricles & $3(38 \%)$ \\
\hline Cortical atrophy & $1(13 \%)$ \\
\hline \multicolumn{2}{|l|}{ Laboratory results } \\
\hline \multicolumn{2}{|l|}{ In blood } \\
\hline C-reactive protein $>5 \mathrm{mg} / \mathrm{L}$ & $2(25 \%)$ \\
\hline Total WBC count $(\mathrm{G} / \mathrm{L})$ & $10.0[6.61-20.75]$ \\
\hline Blood eosinophilia at admission (G/L) & $1.72[0.49-6.43]$ \\
\hline $\begin{array}{l}\text { Blood eosinophilia at admission } \\
\text { (\% of WBC) }\end{array}$ & $12.5[5-31]$ \\
\hline $\begin{array}{l}\text { Max blood eosinophilia during } \\
\text { hospitalisation }(\mathrm{G} / \mathrm{L})\end{array}$ & 2.99 [0.89-6.43] \\
\hline $\begin{array}{l}\text { Max blood eosinophilia during } \\
\text { hospitalisation (\% of WBC) }\end{array}$ & $23.5[10-36]$ \\
\hline A. cantonensis positive serodiagnosis & $7(88 \%)$ \\
\hline \multicolumn{2}{|l|}{ In CSF } \\
\hline Eosinophilia in CSF at first LP $\left(/ \mathrm{mm}^{3}\right)$ & $74.5[0-1550]$ \\
\hline $\begin{array}{l}\text { Eosinophilia in CSF at first LP } \\
(\% \text { of WBC) }\end{array}$ & $25.0[0-68]$ \\
\hline CSF glucose at first LP (mmol/L) & $2.81[0.1-4.3]$ \\
\hline Protein level in CSF at first LP (g/L) & $1.14[0.33-1.71]$ \\
\hline Protein level $>0.45 \mathrm{~g} / \mathrm{L}$ at first $\mathrm{LP}$ & $7(88 \%)$ \\
\hline $\begin{array}{l}\text { Presence of antibodies in CSF (among } \\
\text { those tested) }\end{array}$ & $6(100 \%)$ \\
\hline \multicolumn{2}{|l|}{ Management } \\
\hline Length of hospital stay (days) & 27 [15-66] \\
\hline Subtractive LP & $5(63 \%)$ \\
\hline Corticosteroids & $5(63 \%)$ \\
\hline Anthelmintic therapy & $7(88 \%)$ \\
\hline \multicolumn{2}{|l|}{ Outcome } \\
\hline One year recovery & $2(25 \%)$ \\
\hline One year neurological sequelae & $5(63 \%)$ \\
\hline One year mortality & $1(13 \%)$ \\
\hline
\end{tabular}

Abbreviations: CSF, cerebrospinal fluid; LP, lumbar puncture; WBC, white blood cell.

Descriptive results are presented as $n(\%)$ and as median (min-max).

United States [27], Brazil [32], and some other South American countries $[13,44]$.

In this study, most cases occurred during the rainy season, during which snails abound, particularly the giant African snail, Lissachatina fulica, which was introduced to Martinique in 1989 [31] and is known elsewhere to act as an intermediate host of $A$. cantonensis. In Guadeloupe, A. cantonensis infection in
A. fulica was $32.4 \%$ in 2014 [12]. No doubt other snail and slug species could also act as hosts as there are close to 90 nonmarine mollusc species in Martinique [14, 23]. Numerous rodents have also been reported as potential definitive hosts of A. cantonensis worldwide [49]. Two species of rats, Rattus norvegicus (brown rat) and Rattus rattus (black rat), have been present in the territory since the late 18th century and probably play the role of definitive host of $A$. cantonensis in Martinique as they are the only rodent species in Martinique other than the mouse Mus musculus. No study has evaluated infection of rats with A. cantonensis in Martinique. In neighbouring Grenada [8, 10], Puerto Rico [4], Dominican Republic [45], Haiti [40], Jamaica [46], and Cuba [2], the proportion of infected Rattus spp. varies from $23.4 \%$ to $60.0 \%$ [2, 8], while the parasite appears to be absent in rats in Barbados [25].

Neuroangiostrongyliasis cases in Martinique seem particularly severe relative to other case-series reported in China and South-East Asia, with a higher mortality and sequelae rate. However, given the low number of cases, this must be confirmed as the number of neuroangiostrongyliasis cases increases in Martinique.

All cases were diagnosed by anti-A. cantonensis immunoglobulin detection in serum and/or CSF. Diagnosis was not performed by PCR as it was not available in Martinique or metropolitan France at the time of initial diagnosis [33] and no remaining CSF samples were available in our biobanks. In fact, molecular detection of $A$. cantonensis in CSF was developed in the early 2010s [48] and was only recently validated for clinical use [39]. The recent availability of a specific A. cantonensis PCR test in the French departments of South America and the Caribbean should improve the diagnosis of this disease in this region and encourage local authorities to undertake epidemiological studies on the intermediate and paratenic hosts and reservoirs, which should broaden our understanding of disease transmission in Martinique.

Acknowledgements. We thank the physicians of the University Hospital of Martinique, including medical and clinical biologists, paediatricians, and neurologists for the initial diagnoses of neuroangiostrongyliasis. We thank the Direction de la Recherche Clinique et de l'Innovation (DRCI) of Martinique and the ParasitologyMycology Laboratory of the University Hospital of Grenoble Alpes for their collaboration to the project "Angiostrongylus Research in French Antilles and Guiana". We thank Dr. E. Vandemeulebroucke (Laboratory of Parasitology of the Hospital Centre of Gonesse, Gonesse, France) and Dr. Beatrice Nickel and Dr. Hanspeter Marti at the Swiss Tropical and Public Health Institute, Basel, Switzerland, for performing the serological analyses.

\section{Conflict of interest}

The authors declare that they have no conflict of interest.

\section{References}

1. Aghazadeh M, Jones MK, Aland KV, Reid SA, Traub RJ, McCarthy JS, Lee R. 2015. Emergence of neural angiostrongyliasis in eastern Australia. Vector Borne and Zoonotic Diseases, $15,184-190$. 
2. Aguiar PH, Morera P, Pascual J. 1981. First record of Angiostrongylus cantonensis in Cuba. American Journal of Tropical Medicine and Hygiene, 30, 963-965.

3. Al Hammoud R, Nayes SL, Murphy JR, Heresi GP, Butler IJ, Pérez N. 2017. Angiostrongylus cantonensis meningitis and myelitis, Texas, USA. Emerging Infectious Diseases, 23, $1037-1038$.

4. Andersen E, Gubler DJ, Sorensen K, Beddard J, Ash LR. 1986. First report of Angiostrongylus cantonensis in Puerto Rico. American Journal of Tropical Medicine and Hygiene, 35, 319-322.

5. Ansdell V, Wattanagoon Y. 2018. Angiostrongylus cantonensis in travelers: clinical manifestations, diagnosis, and treatment. Current Opinion in Infectious Diseases, 31, 399-408.

6. Barratt J, Chan D, Sandaradura I, Malik R, Spielman D, Lee R, Marriott D, Harkness J, Ellis J, Stark D. 2016. Angiostrongylus cantonensis: a review of its distribution, molecular biology and clinical significance as a human pathogen. Parasitology, 143, 1087-1118.

7. Bärtschi E, Bordmann G, Blum J, Rothen M. 2004. Eosinophilic meningitis due to Angiostrongylus cantonensis in Switzerland. Infection, 32, 116-118.

8. Chikweto A, Bhaiyat MI, Macpherson CNL, Deallie C, Pinckney RD, Richards C, Sharma RN. 2009. Existence of Angiostrongylus cantonensis in rats (Rattus norvegicus) in Grenada, West Indies. Veterinary Parasitology, 162, 160-162.

9. Chotmongkol V, Kittimongkolma S, Niwattayakul K, Intapan PM, Thavornpitak Y. 2009. Comparison of prednisolone plus albendazole with prednisolone alone for treatment of patients with eosinophilic meningitis. American Journal of Tropical Medicine and Hygiene, 81, 443-445.

10. Coomansingh-Springer C, Vishakha V, Acuna AM, Armstrong E, Sharma RN. 2019. Internal parasitic burdens in brown rats (Rattus norvegicus) from Grenada, West Indies. Heliyon, 5, e02382.

11. Cowie RH. 2013. Pathways for transmission of angiostrongyliasis and the risk of disease associated with them. Hawai'i Journal of Medicine \& Public Health, 72(Supplement 2), 70-74.

12. Dard C, Piloquet J-E, Qvarnstrom Y, Fox LM, M'kada H, Hebert J-C, Mattera D, Harrois D. 2017. First evidence of angiostrongyliasis caused by Angiostrongylus cantonensis in Guadeloupe, Lesser Antilles. American Journal of Tropical Medicine and Hygiene, 96(3), 692-697.

13. Defo AL, Lachaume N, Cuadro-Alvarez E, Maniassom C, Martin E, Njuieyon F, Henaff F, Mrsic Y, Brunelin A, Epelboin L, Blanchet D, Harrois D, Desbois-Nogard N, Qvarnstrom Y, Demar M, Dard C, Elenga N. 2018. Angiostrongylus cantonensis infection of central nervous system, Guiana Shield. Emerging Infectious Diseases, 24, 1153-1155.

14. Delannoye R, Charles L, Pointier J-P, Massemin D. 2015. Nonmarine molluscs of Martinique, Lesser Antilles, in Non-Marine Molluscs of Martinique. Lesser Antilles: Biotope Editions.

15. Dorta-Contreras AJ. 2001. Eosinophilic meningoencephalitis in Cuba. Revista De Neurologia, 32, 999-1000.

16. Dorta-Contreras AJ, Núñez-Fernandez FA, Pérez-Martín O, Lastre-González M, Magraner-Tarrau ME, Bu-Coifiú Fanego R, Noris-García E, Padilla-Docal B, Interián-Morales MT, Martínez-Delgado JF, Sánchez-Zulueta E. 2007. Peculiarities of meningoencephalitis caused by Angiostrongylus cantonensis in America. Revista De Neurologia, 45, 755-763.

17. Eamsobhana P, Gan XX, Ma A, Wang Y, Wanachiwanawin D, Yong HS. 2014. Dot immunogold filtration assay (DIGFA) for the rapid detection of specific antibodies against the rat lungworm Angiostrongylus cantonensis (Nematoda: Metastrongyloidea) using purified $31-\mathrm{kDa}$ antigen. Journal of Helminthology, 88, 396-401.
18. Epelboin L, Blondé R, Chamouine A, Chrisment A, Diancourt L, Villemant N, Atale A, Cadix C, Caro V, Malvy D, Collet L. 2016. Angiostrongylus cantonensis infection on Mayotte Island, Indian Ocean, 2007-2012. PLoS Neglected Tropical Diseases, 10, e0004635.

19. Evans-Gilbert T, Lindo JF, Henry S, Brown P, Christie CDC. 2013. Severe eosinophilic meningitis owing to Angiostrongylus cantonensis in young Jamaican children: case report and literature review. Paediatrics and International Child Health, 34(2), 148-152.

20. Federspiel F, Skovmand S, Skarphedinsson S. 2020. Eosinophilic meningitis due to Angiostrongylus cantonensis in Europe. International Journal of Infectious Diseases, 93, 28-39.

21. Flerlage T, Qvarnstrom Y, Noh J, Devincenzo JP, Madni A, Bagga B, Hysmith ND. 2017. Angiostrongylus cantonensis eosinophilic meningitis in an Infant, Tennessee, USA. Emerging Infectious Diseases, 23, 1756-1758.

22. Graber D, Hebert JC, Jaffar-Bandjee MC, Alessandri JL, Combes JC. 1999. L'angiostrongylose chez le nourrisson à la Réunion et à Mayotte. À propos de trois méningites à éosinophiles dont une radiculomyéloencéphalite avec hydrocéphalie fatale. Bulletin de la Société de Pathologie Exotique, 90, 164-166.

23. Kim JR, Hayes KA, Yeung NW, Cowie RH. 2014. Diverse gastropod hosts of Angiostrongylus cantonensis, the rat lungworm, globally and with a focus on the Hawaiian Islands. PloS One, 9, e94969.

24. Leone S, De Marco M, Ghirga P, Nicastri E, Esposito M, Narciso P. 2007. Eosinophilic meningitis in a returned traveler from Santo Domingo: case report and review. Journal of Travel Medicine, 14, 407-410.

25. Levett PN, Douglas KO, Douglas KA, Waugh CA, Robinson RD, Lindo JF. 2004. Failure to detect Angiostrongylus cantonensis in rats in Barbados. West Indian Medical Journal, 53, 58.

26. Lindo JF, Escoffery CT, Reid B, Codrington G, CunninghamMyrie C, Eberhard ML. 2004. Fatal autochthonous Eosinophilic meningitis in a Jamaican child caused by Angiostrongylus cantonensis. American Journal of Tropical Medicine and Hygiene, 70, 425-428.

27. Liu EW, Schwartz BS, Hysmith ND, DeVincenzo JP, Larson DT, Maves RC, Palazzi DL, Meyer C, Custodio HT, Braza MM, Al Hammoud R, Rao S, Qvarnstrom Y, Yabsley MJ, Bradbury RS, Montgomery SP. 2018. Rat Lungworm Infection Associated with Central Nervous System Disease - Eight U.S. States, January 2011-January 2017. Morbidity and Mortality Weekly Report (MMWR), 67, 825-828.

28. Martínez-Delgado JF, González-Cortiñas M, Tápanes-Cruz TR, Ruiz-Méndez A. 2000. Eosinophilic meningoencephalitis in Villa Clara (Cuba). A study of 17 patients. Revista De Neurologia, 31, 417-421.

29. Martins YC, Tanowitz HB, Kazacos KR. 2015. Central nervous system manifestations of Angiostrongylus cantonensis infection. Acta Tropica, 141, 46-53.

30. Mattis A, Mowatt L, Lue A, Lindo J, Vaughan H. 2009. Ocular angiostrongyliasis-first case report from Jamaica. West Indian Medical Journal, 58, 383-385.

31. Mead A, Palcy L. 1992. Two giant African land snail species spread to Martinique, French West Indies. Veliger, 35, 74-77.

32. Morassutti AL, Thiengo SC, Fernandez M, Sawanyawisuth K, Graeff-Teixeira C. 2014. Eosinophilic meningitis caused by Angiostrongylus cantonensis: an emergent disease in Brazil. Memórias do Instituto Oswaldo Cruz, 109, 399-407.

33. Nguyen Y, Rossi B, Argy N, Baker C, Nickel B, Marti H, Zarrouk V, Houzé S, Fantin B, Lefort A. 2017. Autochthonous case of eosinophilic meningitis caused by Angiostrongylus cantonensis, France, 2016. Emerging Infectious Diseases, 23, 1045-1046. 
34. Nuamtanong S. 1996. The evaluation of the 29 and $31 \mathrm{kDa}$ antigens in female Angiostrongylus cantonensis for serodiagnosis of human angiostrongyliasis. Southeast Asian Journal of Tropical Medicine and Public Health, 27, 291-296.

35. Oehler E, Ghawche F, Delattre A, Berberian A, Levy M, Valour F. 2014. Angiostrongylus cantonensis eosinophilic meningitis: a clinical study of 42 consecutive cases in French Polynesia. Parasitology International, 63, 544-549.

36. Padilla-Docal B, Dorta-Contreras AJ, Moreira JM, MartiniRobles L, Muzzio-Aroca J, Alarcón F, Magraner-Tarrau ME, Bu-Coifiu-Fanego R. 2011. Comparison of major immunoglobulins intrathecal synthesis patterns in Ecuadorian and Cuban patients with angiostrongyliasis. American Journal of Tropical Medicine and Hygiene, 84, 406-410.

37. Pérez Martín O, Lastre González M, Duménigo Ripoll B, Aguiar Prieto PH, Aguilera A. 1984. Infestation by Angiostrongylus cantonensis in the Havana Provinces. Revista Cubana De Medicina Tropical, 36, 54-58.

38. ProMEDmail.org. 2001. ProMED <https://promedmail.org>. Archive: 20011007.2426. International Society for Infectious Diseases.

39. Qvarnstrom Y, Xayavong M, Aramburu da Silva AC, Park SY, Whelen AC, Calimlim PS, Sciulli RH, Honda SAA, Higa K, Kitsutani P, Chea N, Heng S, Johnson S, Graeff-Teixeira C, Fox LM, Da Silva AJ. 2015. Real-time polymerase chain reaction detection of Angiostrongylus cantonensis DNA in cerebrospinal fluid from patients with eosinophilic meningitis. American Journal of Tropical Medicine and Hygiene, 94(1), 176-181.

40. Raccurt CP, Blaise J, Durette-Desset M-C. 2003. Presence of Angiostrongylus cantonensis in Haiti. Tropical Medicine \& International Health, 8, 423-426.

41. Rau C, Bialek R, Richter S, Lindner A. 2006. Headache after a stay in the Dominican Republic. Deutsche Medizinische Wochenschrift (1946), 131, 1656-1659.
42. Slom TJ, Cortese MM, Gerber SI, Jones RC, Holtz TH, Lopez AS, Zambrano CH, Sufit RL, Sakolvaree Y, Chaicumpa W, Herwaldt BL, Johnson S. 2002. An outbreak of eosinophilic meningitis caused by Angiostrongylus cantonensis in travelers returning from the Caribbean. New England Journal of Medicine, 346, 668-675.

43. Thanaviratananich S, Thanaviratananich S, Ngamjarus C. 2015. Corticosteroids for parasitic eosinophilic meningitis. Cochrane Database of Systematic Reviews, 2, CD009088.

44. Valente R, Robles MDR, Navone GT, Diaz JI. 2018. Angiostrongylus spp. in the Americas: geographical and chronological distribution of definitive hosts versus disease reports. Memórias do Instituto Oswaldo Cruz, 113, 143-152.

45. Vargas M, Gomez Perez JD, Malek EA. 1992. First record of Angiostrongylus cantonensis (Chen, 1935) (Nematoda: Metastrongylidae) in the Dominican Republic. Tropical Medicine and Parasitology, 43, 253-255.

46. Waugh CA, Lindo JF, Lorenzo-Morales J, Robinson RD. 2016. An epidemiological study of Angiostrongylus cantonensis in Jamaica subsequent to an outbreak of human cases of eosinophilic meningitis in 2000. Parasitology, 143, 1211-1217.

47. Welch JS, Dobson C, Campbell GR. 1980. Immunodiagnosis and seroepidemiology of Angiostrongylus cantonensis zoonoses in man. Transactions of the Royal Society of Tropical Medicine and Hygiene, 74, 614-623.

48. Wilkins PP, Qvarnstrom Y, Whelen AC, Saucier C, da Silva AJ, Eamsobhana P. 2013. The current status of laboratory diagnosis of Angiostrongylus cantonensis infections in humans using serologic and molecular methods. Hawai'i Journal of Medicine \& Public Health, 72, 55-57.

49. Yong HS, Eamsobhana P. 2013. Definitive rodent hosts of the rat lungworm Angiostrongylus cantonensis. Raffles Bulletin of Zoology, 29 (Supple.29), 111-115.

Cite this article as: Dard C, Tessier E, Nguyen D, Epelboin L, Harrois D, Swale C, Cabié A, de Meuron K, Miossec C \& Desbois-Nogard N. 2020. First cases of Angiostrongylus cantonensis infection reported in Martinique, 2002-2017. Parasite $27,31$.

Reviews, articles and short notes may be submitted. Fields include, but are not limited to: general, medical and veterinary parasitology; morphology, including ultrastructure; parasite systematics, including entomology, acarology, helminthology and protistology, and molecular analyses; molecular biology and biochemistry; immunology of parasitic diseases; host-parasite relationships; ecology and life history of parasites; epidemiology; therapeutics; new diagnostic tools.

All papers in Parasite are published in English. Manuscripts should have a broad interest and must not have been published or submitted elsewhere. No limit is imposed on the length of manuscripts.

Parasite (open-access) continues Parasite (print and online editions, 1994-2012) and Annales de Parasitologie Humaine et Comparée (1923-1993) and is the official journal of the Société Française de Parasitologie. 